\title{
The vaginal smear, mating, egg transport and preimplantation development in a wild guinea-pig, the cuis (Galea musteloides)
}

\author{
M. L. Norris and C. E. Adams \\ A.R.C. Institute of Animal Physiology, Animal Research Station, Cambridge CB3 OJQ, U.K.
}

\begin{abstract}
Summary. Observations were made on vaginal smear pattern, mating, rate of egg transport and preimplantation development in cuis. In 39 of 45 females (87\%) vaginal opening occurred within 2 days of pairing, and in 44 (98\%) within 5 days; 36 of the 44 females (82\%) mated. By the morning of Day 2, eggs were no longer recovered from the ampulla, having all passed into the isthmus, where they remained till Day 4, p.m. Uterine entry was complete by Day 5, a.m. Uterine blastocysts were no longer recoverable on the morning of Day 6. There was no evidence of blastocyst expansion or zona shedding before implantation.
\end{abstract}

\section{Introduction}

The cuis (Galea musteloides), a species of wild guinea-pig, was first reared under laboratory conditions by Weir $(1967,1970)$, who together with Rood (Rood \& Weir, 1970) described some of the basic reproductive characteristics of this species. Like the guinea-pig and most other hystricomorph rodents, the cuis has a vaginal closure membrane (Weir, 1974). Perforation of this membrane first occurs at about 48 days of age but when females are isolated no vaginal openings occur (Weir, 1970). However, the introduction of a male quickly leads to vaginal opening and oestrus (Weir, 1973). Oestrus also occurs immediately post partum when the majority of females mate (Weir, 1970). The vaginal closure membrane is open for 1 to 6 days at oestrus and parturition: it closes rapidly following mating (Rood \& Weir, 1970). Ovulation is induced by coitus, only 13-20\% of females exhibiting spontaneous oestrous cycles and only half of these ovulating (Weir, 1973, 1974). Observations on the embryology of the cuis and some other hystricomorph rodents have been reported by Roberts (1973) and Roberts \& Perry (1974).

The present work was undertaken, as part of a larger comparative project, to obtain data on egg transport and development up to the time of implantation.

\section{Materials and Methods}

The animals used in this study were derived from foundation stock kindly supplied by $\mathrm{Dr}$ B. J. Weir. After removal from the breeding groups at 20 days of age, females were kept in groups of 3 to 6 in polypropylene boxes, measuring $56 \times 36 \times 18 \mathrm{~cm}$ (type RC1, North Kent Plastic Cages Ltd, Dartford, Kent), in which sawdust was used as bedding. Diet 18 (Dixon \& Sons, Ware, Herts) and fresh water were always available. The room temperature was maintained at $21 \pm 1^{\circ} \mathrm{C}$; artificial light was supplied between 05:00 and 19:00 h. Each of 45 virgin females, mean age 127 days (range 82-169 days) and weighing $299 \mathrm{~g}$ (range 230-367 g), was placed with a proven male at $17: 30 \mathrm{~h}$ on a Monday; he was removed at $09: 30 \mathrm{~h}$ the following morning and 
the sequence was repeated daily until mating was confirmed by means of a sperm-positive vaginal smear (designated Day 1). Vaginal smears were obtained by lavage using sterile $0.9 \%$ $(w / v)$ sodium chloride. Smears were examined microscopically $(x 80)$ shortly after collection and the cell types present and their relative incidence were noted. Males were rested between $09: 30 \mathrm{~h}$ on Saturday and 17:30 h on Monday. The total test period extended over 20 days or until mating, whichever was the shorter.

Mated females were autopsied between Days 1 and 6 post coitum ( $p . c$.$) . After removal of the$ entire genital tract, the oviducts were separated and, after straightening, divided into two equal segments, henceforth referred to as 'ampulla' and 'isthmus'. Both oviducts and uterine horns were flushed with phosphate-buffered saline, $\mathrm{pH} 7.2$ (Dulbecco 'A': Oxoid Ltd, London). The flushings, which were collected into punted watchglasses, were immediately searched for eggs. After classifying the eggs according to stage of development the majority were measured, using an ocular micrometer (E. Leitz, Wetzlar, Germany). In each case, 4 measurements were made across the outer and inner aspects of the zona pellucida along two axes at right angles to each other. Representative eggs from each female were photographed. Whenever it proved impossible to count the number of blastomeres, spreads were made as described by Tarkowski (1966). Preparations were air-dried and stained with $0.1 \%$ toluidene blue (G. T. Gurr, High Wycombe, Bucks). Cell numbers were either counted under the microscope or after photography.

\section{Results}

\section{Vaginal opening and mating}

In 39 out of 45 females ( $87 \%$ ) vaginal opening occurred within 2 days following pairing and in all except 1 , which remained imperforate, by the 5 th day $(98 \%)$.

Of the 44 females showing vaginal opening $36(82 \%)$ mated. In 17 cases $(47 \%)$ spermatozoa were present on the day of vaginal opening, in 7 (19\%) on the following day, in $3(8 \%)$ after 2 days, in $2(6 \%)$ after 3 days and in $1(3 \%)$ after 5 days; the remaining 6 females $(17 \%)$ mated between 7 and 19 days after pairing. More than half of the females mated either at or within $24 \mathrm{~h}$ of vaginal opening.

\section{EXPLANATION OF PLATE 1}

Fig. 1. Day 1 (a.m.), showing a 1-cell egg recovered from the 'ampulla'; 2 polar bodies are visible in the perivitelline space. $\times 395$.

Fig. 2. Day 2 (a.m.); a 2-cell egg recovered from the 'isthmus'. Dark yolk granules are evident in the ooplasm. $\times 395$.

Fig. 3. Day 3 (a.m.). A 4-cell egg recovered from the 'isthmus', 1 blastomere is out of focus. Note striations in the zona pellucida. $\times 395$.

Fig. 4. Day 4 (a.m.). Morula recovered from the 'isthmus'. $\times 395$.

Fig. 5. Day 4 (p.m.). Late morula recovered from the uterus. Note irregular surface of zona pellucida. $\times 395$.

Fig. 6. Day 5 (a.m.). Blastocyst recovered from the uterus, showing differentiation into inner cell mass and trophectoderm. Note spermatozoa attached to the zona pellucida. $\times 395$.

Fig. 7. Day 5 (p.m.). Blastocyst recovered from the uterus. Note presence of a large cavity, well differentiated inner cell mass and trophectoderm layer. The zona pellucida is unchanged in size. $\times 395$.

Fig. 8. Cell spread of the late morula depicted in Fig. 5. There are 32 cells present and the blastomeres are covered by dispersed yolk granules. $\times 245$. 
PLATE 1
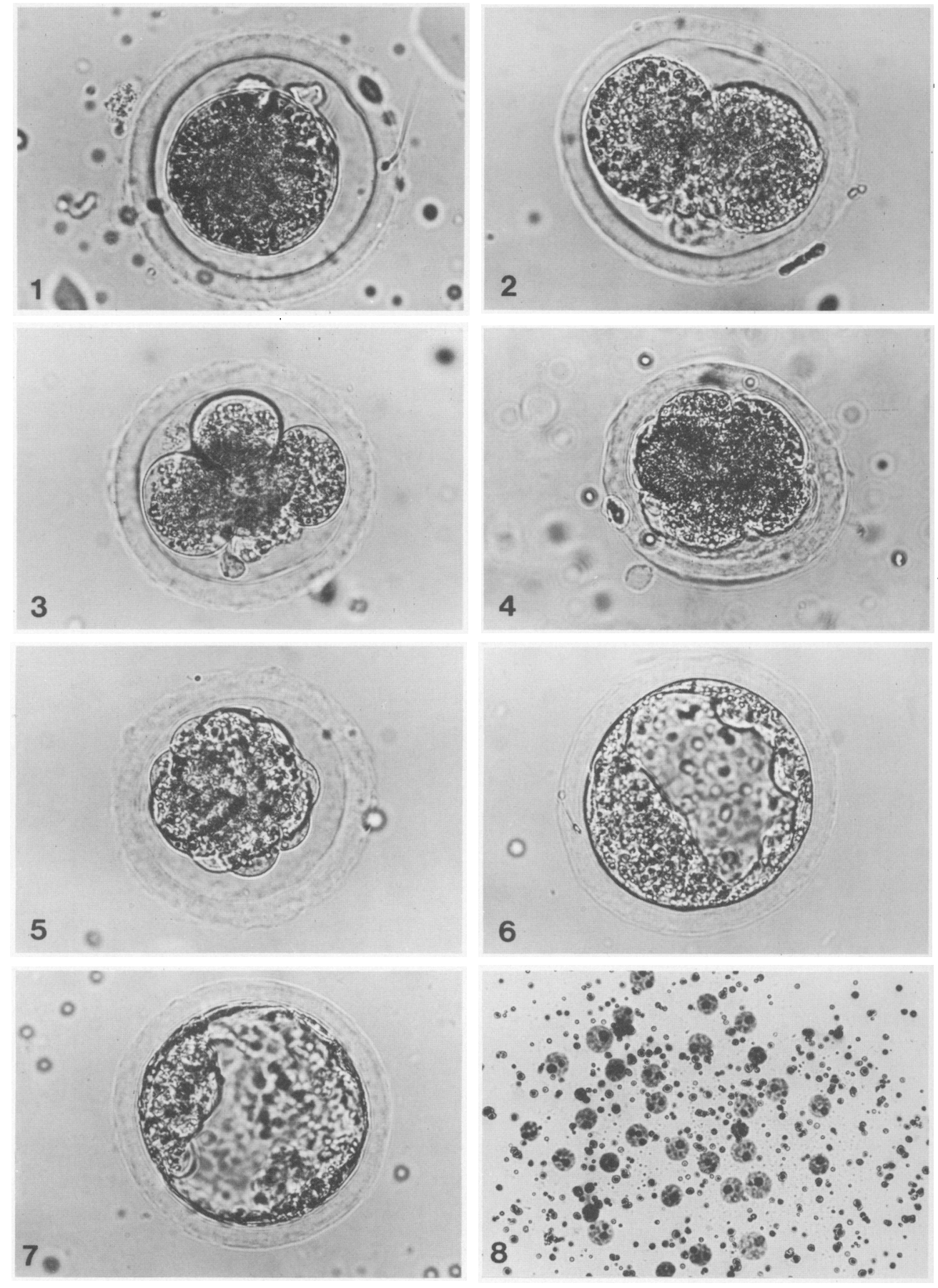


\section{The vaginal smear}

The most common associations of cells found were leucocytes with epithelial, epithelial with cornified and cornified either alone or with epithelial cells. The majority of smears contained leucocytes as the dominant cell type. Data relating the dominant cell type to female receptivity are presented in Table 1. The proportion of females having full vaginal cornification increased at the time of mating when there was an associated decrease in the proportion of smears showing a preponderance of leucocytes. However, the majority of females mating did so without cornification being detected.

Thirty-six (36) 'post coital' smears were evaluated for sperm motility. The spermatozoa were motile in $29(80 \%)$ females: less than $50 \%$ of spermatozoa were motile in $19(66 \%)$ females and more than $50 \%$ in $10(34 \%)$. The number of spermatozoa present varied greatly from 2 to 3 per field to more than 100 .

Table 1. The character of the 254 vaginal smears taken before and at mating (Day 1) in cuis

\begin{tabular}{lcrr}
\hline \multirow{2}{*}{$\begin{array}{c}\text { Dominant cell } \\
\text { type }\end{array}$} & \multicolumn{3}{c}{ Time (days) from mating } \\
\cline { 2 - 4 } & $\geqslant-2$ & \multicolumn{1}{c}{-1} & \multicolumn{1}{c}{1} \\
\hline Leucocyte & $168(84)$ & $12(63)$ & $21(58)$ \\
Epithelial & $11(6)$ & $2(11)$ & $4(11)$ \\
Cornified & $20(10)$ & $5(26)$ & $11(31)$ \\
\hline
\end{tabular}

Values in parentheses are percentages.

\section{Autopsy findings}

Of the 36 females autopsied between Days 1 and 6, 6 had pyometritic uteri and were not considered further; 25 of the remaining $30(83 \%)$ yielded normal eggs. The number of corpora lutea per female was $4.47 \pm 0.14$ (s.e.m.); equal numbers were present on the left $(2.23 \pm 0 \cdot 16)$ and right ovaries $(2 \cdot 23 \pm 0.20)$. Of 68 eggs, equivalent to $93 \%$ of the corpora lutea, recovered from 21 females, $9(13 \%)$ were classified as unfertilized or degenerate. During Days 1 to 5 no eggs were recovered from 4 females, and 1 female yielded only unfertilized eggs. Details of egg recovery relative to time elapsing from mating are given in Table 2. Throughout Day 1, all eggs were found in the 'ampulla', but all were recovered from the 'isthmus' on the morning of Day 2.

Table 2. Site and efficiency of egg recovery in cuis

\begin{tabular}{|c|c|c|c|c|c|c|}
\hline \multirow{2}{*}{$\begin{array}{c}\text { Time } \\
\text { (days p.c.) }\end{array}$} & \multicolumn{3}{|c|}{ No. of: } & \multicolumn{3}{|c|}{ Site and no. (\%) of eggs recovered } \\
\hline & QP & $\mathrm{CL}$ & Eggs (\%) & Ampulla & Isthmus & Uterus \\
\hline 1-a.m. & 1 & 5 & $5(100)$ & $5(100)$ & 0 & 0 \\
\hline 一p.m. & 2 & 9 & $7(78)$ & $7(100)$ & 0 & 0 \\
\hline 2-a.m. & 3 & 13 & $13(100)$ & 0 & $13(100)$ & 0 \\
\hline 3-a.m. & 3 & 13 & $12(92)$ & 0 & $12(100)$ & 0 \\
\hline 4-a.m. & 3 & 15 & $6(40)$ & 0 & $5(83)$ & $1(17)$ \\
\hline -p.m. & 2 & 10 & $6(60)$ & 0 & $2(33)$ & $4(67)$ \\
\hline 5-a.m. & 3 & 14 & $11(79)$ & 0 & 0 & $11(100)$ \\
\hline 一p.m. & 3 & 10 & $4(40)$ & 0 & 0 & $4(100)$ \\
\hline 6-a.m. & 5 & 23 & 0 & 0 & 0 & 0 \\
\hline
\end{tabular}

a.m. $=09: 00-10: 00$ h; p.m. $=17: 00-18: 00$ h. 
Then followed a prolonged sojourn in the 'isthmus'. The yield of eggs was reduced on Day 4, coinciding with entry into the uterus, which was complete by Day 5 (a.m.). The much reduced rate of recovery on Day 5 (p.m.) suggests that blastocyst attachment was already in progress whilst the total failure of recovery on Day 6 is indicative of its completion.

Representative examples of the recovered eggs are illustrated in PI. 1, Figs 1-8. The eggs were characterized by a very dark-coloured, granular ooplasm in which yolk granules were unevenly distributed; their persistence tended to mask otherwise satisfactory blastocyst spreads (PI. 1, Fig. 8). The zona pellucida mostly showed prominent radial striations and surface irregularities. Polar bodies observed in newly fertilized eggs usually had indistinct, irregular outlines (PI. 1, Fig. 1); early fragmentation and cytolysis of the polar bodies seemed to be the rule. The first morulae were observed on Day 4. Cavitation occurred during Day 4 and only blastocysts were recovered on Day 5. It therefore appears that cavitation occurs quickly once the egg enters the uterus. No zona-free blastocysts or empty zonas were recovered.

A total of 44 eggs from 15 females was measured and the results, including cell counts, based on 57 eggs from 19 females, are presented in Table 3. No significant changes in either egg size (slightly in excess of $100 \mu \mathrm{m}$ ) or shape were noted; the zona pellucida remained relatively constant at $8-10 \mu \mathrm{m}$. Initially, the cleavage rate was slow: it was fastest between Days 4 and 5 .

Table 3. Egg measurements (mean \pm s.e.m.) and rate of development up to the time of implantation in cuis

\begin{tabular}{|c|c|c|c|c|c|c|c|}
\hline \multirow{3}{*}{$\begin{array}{c}\text { Time } \\
\text { (days p.c.) }\end{array}$} & \multicolumn{4}{|c|}{ Egg measurements } & \multicolumn{3}{|c|}{ Rate of development } \\
\hline & \multicolumn{2}{|c|}{ No. of: } & \multirow{2}{*}{$\begin{array}{l}\text { Diameter } \\
(\mu \mathrm{m})\end{array}$} & \multirow{2}{*}{$\begin{array}{c}\text { Thickness of } \\
\text { zona pellucida } \\
(\mu \mathrm{m})\end{array}$} & \multicolumn{2}{|c|}{ No. of: } & \multirow{2}{*}{$\begin{array}{l}\text { No. of } \\
\text { cells/egg }\end{array}$} \\
\hline & $q 9$ & Eggs & & & 우 & Eggs & \\
\hline $1-$ a.m. & 1 & 5 & $114 \cdot 2 \pm 1 \cdot 6$ & $10.0 \pm 0.4$ & 1 & 5 & 1.0 \\
\hline - p.m. & - & - & - & - & 2 & 7 & 1.0 \\
\hline 2 -a.m. & 3 & 11 & $112.6 \pm 1.7$ & $10 \cdot 1 \pm 0.2$ & 3 & 11 & $3.5 \pm 0.2$ \\
\hline 3 -a.m. & 1 & 4 & $114.8 \pm 1.9$ & $8.4 \pm 0.8$ & 3 & 11 & 4.0 \\
\hline 4-a.m. & 3 & 6 & $102.7 \pm 1.3$ & $9.0 \pm 0.5$ & 3 & 6 & $9.0+1.4$ \\
\hline - p.m. & 2 & 6 & $107.8 \pm 0.2$ & $9.5 \pm 0.3$ & 2 & 6 & $27.8 \pm 3.1$ \\
\hline 5-a.m. & 3 & 10 & $112.9 \pm 1.7$ & $10.2 \pm 0.5$ & 3 & 9 & $51.8 \pm 2.1$ \\
\hline - p.m. & 2 & 2 & $107.7 \pm 1.9$ & $10 \cdot 1 \pm 1.4$ & 2 & 2 & $57.0+1.0$ \\
\hline
\end{tabular}

a.m. $=09: 00-10: 00$ h; p.m. $=17: 00-18: 00$ h.

\section{Discussion}

Our finding that the interval from first pairing to vaginal opening and mating is very brief accords fully with observations of Weir (1973) on male-induced oestrus in cuis. Whilst there was evidence for an increase in vaginal cornification at the time of mating, the majority of females which mated showed leucocyte and epithelial cell-dominated smears. The lack of relationship between behavioural oestrus and full vaginal cornification could be due to cornified elements being present initially only in the anterior region of the vagina or to the male factor over-riding the basic ovarian rhythm, as suggested by Weir (1971). The inherent rhythm of females placed with a vasectomized male is about 20 days (Weir, 1970,1974) and so the animals in the present study were almost certainly mating at the first induced oestrus.

Although some animals were not considered further because of an apparent metritis, this may not be an abnormal condition in this species because it has been observed in females isolated from males at an early age (B. J. Weir, personal communication). Such females do not 
become oestrous until a male is introduced (Weir, 1973) and since nearly all cuis then become pregnant, as in the present study, the occurrence of metritis is probably not a bar to reproduction in cuis.

Present results indicate that in cuis the eggs spend a relatively short time in the ampulla (1 day) and considerably longer ( $>2$ days) in the isthmus, with a slow initial rate of cleavage, as found by Squier (1932) for the guinea-pig. Squier (1932) reported that all eggs were 1-celled and present in the "top half" of the oviduct up to $30 \mathrm{~h}$ p.c. During the next $50 \mathrm{~h}$, it was noted that the eggs passed slowly through the rest of the oviduct to arrive at the utero-tubal junction at the 8cell stage by 80 h p.c. Squier's results, however, differ from those of Maia, Salinas, Fernandez \& Pauerstein (1977), who recorded a long sojourn in the 'ampulla' and rapid transport through the 'isthmus'. However the observations of Maia et al. were based on cyclic, unmated guinea-pigs, while we, and Squier, used mated females. The possibility exists, therefore, that the pattern of movement of the unfertilized egg may be different from that of the fertilized egg.

In certain respects, the zona pellucida resembled that of the chinchilla egg, as described by Roberts \& Perry (1974), who also drew attention to the difficulty in detecting polar bodies, spermatozoa or pronuclei in newly fertilized eggs of hystricomorphs. There was a notable lack of blastocyst expansion or zona thinning. Moreover, the total absence of zona-free blastocysts or empty zonas near the time of implantation provides additional evidence that in cuis the zona is retained, as it is in the guinea-pig (Amoroso, 1959), until implantation has begun.

The present observations generally confirm the suggestion of Roberts (1973) that the timing of preimplantation events in cuis is essentially similar to that in the domestic guinea-pig, as reported by Squier (1932). However, cuis are able to reproduce at an earlier age than domestic guinea-pigs (successful conceptions from matings at 9 days of age have been reported: Weir, 1974, and personal communication), and could therefore be more convenient for study of some aspects of reproductive physiology.

We are indebted to Dr Barbara Weir for providing our foundation stock of cuis, for advice on their management, and for her continuing interest and help.

\section{References}

Amoroso, E.C. (1959) The attachment cone of the guinea-pig blastocyst as observed under time lapse phase contrast cinematography. In Implantation of Ova, pp. 50-51. Ed. P. Eckstein. Cambridge University Press.

Maia, H., Salinas, L.A., Fernandez, E. \& Pauerstein, C.J. (1977) Time course of ovum transport in guinea pigs. Fert. Steril. 28, 863-865.

Roberts, C.M. (1973) The embryology of certain hystricomorph rodents. Ph.D. thesis, University of London.

Roberts, C.M. \& Perry, J.S. (1974) Hystricomorph embryology. Symp. zool. Soc. Lond. 34, 333-360.

Rood, J.P. \& Weir, B.J. (1970) Reproduction in female wild guinea-pigs. J. Reprod. Fert. 23, 393-409.

Squier, R.R. (1932) The living egg and early stages of its development in the guinea pig. Contr. Embryol. Carneg. Instn 137, 225-250.
Tarkowski, A.K. (1966) An air-drying method for chromosome preparations from mouse eggs. Cytogenetics 5, 394-400.

Weir, B.J. (1967) The care and management of laboratory hystricomorph rodents. Lab. Anim. 1, 95-104.

Weir, B.J. (1970) The management and breeding of some more hystricomorph rodents. Lab. Anim. 4, 83-97.

Weir. B.J. (1971) The evocation of oestrus in the cuis, Galea musteloides. J. Reprod. Fert. 26, 405-408.

Weir, B.J. (1973) The rôle of the male in the evocation of oestrus in the cuis, Galea musteloides (Rodentia: Hystricomorpha). J. Reprod. Fert., Suppl. 19, 421432.

Weir, B.J. (1974) Reproductive characteristics of hystricomorph rodents. Symp. zool. Soc. Lond. 34, 265301 . 